\title{
PHYSICAL ACTIVITY OF THE ELDERLY: LIMITATIONS AND KNOWLEDGE ABOUT THE DANGERS OF HYPOKINESIA
}

\section{AKTYWNOŚĆ FIZYCZNA OSÓB STARSZYCH Z UWZGLĘDNIENIEM BARIER I WIEDZY O ZAGROŻENIACH ZWIĄZANYCH Z HIPOKINEZJĄ}

\author{
Zofia Kubińska $^{1(\mathrm{~A}, \mathrm{~B}, \mathrm{C}, \mathrm{D}, \mathrm{E}, \mathrm{F}, \mathrm{G})}$, Anna Pańczuk ${ }^{1(\mathrm{~A}, \mathrm{C}, \mathrm{D}, \mathrm{E}, \mathrm{F}, \mathrm{G})}$ \\ ${ }^{1}$ Department of Physiotherapy, Pope John Paul II State School of Higher Education in Biała Podlaska, Poland
}

Authors' contribution Wkład autorów:

A. Study design/planning zaplanowanie badań

B. Data collection/entry zebranie danych

C. Data analysis/statistics dane - analiza i statystyki D. Data interpretation interpretacja danych E. Preparation of manuscript przygotowanie artykułu F. Literature analysis/search wyszukiwanie i analiza literatury G. Funds collection zebranie funduszy
Tables: 1

Figures: 4

References: 25

Submitted: 2020 Oct 25

Accepted: 2021 March 23

\section{Summary}

Background. Researchers often discuss the subject of physical activity (PA) of the elderly in theoretical terms, showing, for example, the protective mechanisms of PA for the body, beneficial effects for health and aging, as well as the principles of effective health training. According to the WHO and EU, few elderly people are physically active. This study aimed to investigate the level of PA of the surveyed elderly people at the present time, compared to when they were younger. Potential limitations in PA of the respondents and their knowledge about the dangers of hypokinesia were also investigated.

Material and methods. This study assessed 217 people, aged 60-85, living in the northern part of the Lublin Province, Poland. It used an original interview questionnaire.

Results. Systematic PA performed by respondents earlier in life involved mainly household and backyard activities, professional work, and participation in physical education lessons. The currently most frequent activities were found to be walking $(75.6 \%)$ and gardening $(66.4 \%)$. Women much more often than men participated and reported their willingness to be active in organized PA. Various limitations prevented respondents from being physically active. The greatest number of respondents reported disability, physical weakness, kinesiophobia, and multiple diseases (34.6\%) as the main barrier, followed by lack of skills to organize physical exercises $(27.7 \%)$. Concerning threats of hypokinesia, respondents most often indicated obesity, diseases of the musculoskeletal system, and arterial hypertension. Conclusions. The level of PA of the surveyed elderly people, limitations preventing PA, and low level of knowledge about the delayed consequences of hypokinesia suggests a need for seniors' health education in physioprophylaxis.

Keywords: physical activity, elderly, hypokinesia, limitations

\section{Streszczenie}

Wprowadzenie. W ujęciu teoretycznym naukowcy często podejmują temat aktywności fizycznej (AF) seniorów, ukazując, np. mechanizmy ochronne działania AF na organizm, jej wpływ na zdrowie, pozytywne starzenie się oraz zasady skutecznego treningu zdrowotnego. Według WHO i UE niewiele osób starszych jest aktywnych fizycznie. Celem pracy jest ukazanie zróżnicowania aktywności fizycznej badanych seniorów we wcześniejszym i obecnym okresie życia. Postanowiono również przedstawić bariery ograniczające badanym podejmowanie aktywności fizycznej oraz ich wiedzę na temat zagrożeń wynikających z hipokinezji.

Materiał i metody. Badania przeprowadzono wśród 217 osób w wieku 60-85 lat zamieszkałych na terenie północnej część województwa lubelskiego, Polska. Wykorzystano w nich autorski kwestionariusz wywiadu.

Wyniki. Systematyczna aktywność fizyczna podejmowana przez badanych we wcześniejszym okresie życia realizowana była głównie poprzez czynności domowe i przydomowe, pracę zawodową oraz uczestniczenie w lekcjach wychowania fizycznego. Obecnie najczęściej podejmowanymi aktywnościami są spacery $(75,6 \%)$ i praca w ogrodzie $(66,4 \%)$. Kobiety znacznie częściej niż mężczyźni uczestniczą i zgłaszają chęć aktywności w zorganizowanych zajęciach ruchowych. Wśród barier uniemożliwiających ankietowanym aktywność fizyczną najwięcej osób zadeklarowało własną niepełnosprawność, słabość fizyczną, kinezjofobię, wielochorobowość $(34,6 \%)$. W dalszej kolejności deklarowano brak umiejętności do zorganizowania ćwiczeń fizycznych (27,7\%). Wśród zagrożeń hipokinezji badani wskazywali najczęściej: otyłość, choroby narządu ruchu i nadciśnienie tętnicze.

Wnioski. Aktywność fizyczna w życiu badanych seniorów, bariery uniemożliwiające podejmowanie aktywności fizycznej i niski poziom wiedzy na temat odroczonych konsekwencji hipokinezji sugerują potrzebę edukacji zdrowotnej seniorów z fizjoprofilaktyki.

Słowa kluczowe: aktywność fizyczna, osoby starsze, hipokinezja, bariery 


\section{Introduction}

The results of the research have repeatedly confirmed that systematic physical activity (PA) of elderly people is a factor that protects their health and ensures successful aging, both in healthy people and those with diagnosed chronic diseases. According to many authors, PA is important for the prevention of overweight and obesity, atherosclerosis, hypertension, diabetes, cancer (of colon and breast), osteoporosis, metabolic syndrome, and falls in the elderly. It has a positive effect on mental performance, reduces the incidence of depression and the risk of dementia, improves functionally, and extends life [1-7]. The 10 guidelines of the Polish Forum for Prophylaxis (2010) on PA state that its promotion should begin in early childhood and continue until late old age [8].

Researchers often discuss the subject of PA of the elderly in theoretical terms, showing, for example, the protective mechanisms of PA for the body, beneficial effects for health and aging, as well as the principles of effective aerobic, resistance, and coordination health training [9-13]. Special attention is deserved by Osiński's scientific works, including the textbook: "Gerokynesiology. Learning and practicing physical activity in old age" [14]. We only need to find a way to reach elderly people with this knowledge, and it would probably be an effective motivation to change their sedentary behavior to active behavior. The problem is still where and with whom the currently large population of elderly people could pursue health-promoting PA. Organized PA classes for elderly people are conducted only by scarce Third Age Universities and Senior Clubs [15].

It is a very difficult task to persuade "health politicians" to make the expected organizational decisions, although they declare awareness and understanding of the essence of physical culture as a factor protecting the health of elderly people. In the past, activities for older people were recommended several times by the WHO and EU guidelines to be implemented in European countries [16-18]. After 2012, declared by the European Parliament the European Year for Active Ageing and Solidarity between Generations [19], the pace and scope of activities socially engaging elderly people in Poland slightly accelerated. However, this does not apply to PA of the elderly people.

According to the study by the Central Statistical Office (GUS), of people over 60 years of age who regularly participated in sport and physical recreation in 2016, there were $10.6 \%$ of women and $10.9 \%$ of men. $40.5 \%$ of all elderly people exercised for pleasure, and $31.7 \%$ for health due to medical recommendations [20].

This study aimed to investigate the level of PA of the surveyed elderly people at the present time, compared to when they were younger. Potential limitations in PA of the respondents' and their knowledge about the dangers of hypokinesia were also investigated.

\section{Material and methods}

The study was conducted at the turn of 2018 and 2019 on 217 elderly people who agreed to participate. The respondents were people aged 60-85 (mean 69.5) living in the northern part of the Lublin Province, Poland. Women, who constituted $65 \%$ of respondents, were in the age from 60 to 85 years, and their mean age was 69.3 years. Men, constituting $35 \%$ of respondents, were also aged $60-85$, and their mean age was 70.0 years. The majority of respondents were inhabitants of rural areas (57\%). The most numerous group of respondents had vocational education (41\%), followed by secondary (29\%), primary (19\%), and higher (11\%) education. Most respondents assessed their health as good (60\%), 8\% assessed it as very good, $27 \%$ considered their health to be bad and 5\% regarded it as very bad.

In the actual study, an original interview questionnaire, modified after the pilot study, was used. The survey data was obtained in a face-to-face interview by trained interviewers. The questionnaire included closed and semi-open questions and a birth certificate (gender, age, place of residence, and education). The closed questions concerned the self-assessment of the present state of health and participation in PA to date. The semi-open questions concerned the currently done PA, whose level respondents would like to keep, the limitations that prevent PA, and the knowledge about the consequences of hypokinesia. Data are presented as percentages. The chi-square (Pearson) test with Yates correction was used to test the relationship between the analyzed variables and gender. A significance level of $\mathrm{p}<0.05$ was adopted in the statistical inference. The computer software STATISTICA v. 7.1 (StatSoft, Poland) was used for statistical analysis.

\section{Results}

So far, the participation of respondents in PA has been most often sporadic (46.3\%), less often systematic (31.0\%) or minimal $(22.7 \%)$. The most numerous group indicated systematic participation in PA related to 
household and backyard chores (75.5\%), professional work (61.1\%) and physical education lessons during school times (59.7\%). A large group of respondents reported that they undertook systematic PA related to transport (50.5\%) and family life (41.7\%). Only a few systematically participated in training provided by non-school sports clubs (6.5\%), training by the school sports club (15.3\%), and PA having corrective and rehabilitation functions (9.8\%). Free-time PA (related to a hobby, tourism, and recreation) was done systematically by only $13.8 \%$ of respondents, and $26.3 \%$ did not do it at all. Detailed results are presented in Table 1.

Table 1. Differentiation of physical activity done by respondents in their lives, taking to account the regularity

\begin{tabular}{|c|c|c|c|}
\hline Physical activity & Systematically & Incidentally & I did not participate \\
\hline Physical education lessons & $59.7 \%$ & $25.5 \%$ & $14.8 \%$ \\
\hline School sports club (SKS) & $15.3 \%$ & $24.5 \%$ & $60.2 \%$ \\
\hline Training in non-school sports clubs & $6.5 \%$ & $12.5 \%$ & $81.0 \%$ \\
\hline PA at home and in the backyard & $75.5 \%$ & $22.7 \%$ & $1.8 \%$ \\
\hline PA at work & $61.1 \%$ & $27.8 \%$ & $5.1 \%$ \\
\hline PA related to transport & $50.5 \%$ & $44.4 \%$ & $8.8 \%$ \\
\hline PA related to family life & $41.7 \%$ & $49.5 \%$ & $46.5 \%$ \\
\hline $\begin{array}{c}\text { PA meant to reach correctional and } \\
\text { rehabilitation goals }\end{array}$ & $9.8 \%$ & $43.7 \%$ & $26.3 \%$ \\
\hline $\begin{array}{c}\text { PA related to a hobby, tourism, and } \\
\text { recreation (free time) }\end{array}$ & $13.8 \%$ & $59.9 \%$ & \multirow{2}{*}{} \\
\hline
\end{tabular}

The currently most frequently activities were found to be walking (75.6\%) and gardening (66.4\%) (Figure 1). Cycling was third (48.4\%). $6.0 \%$ of the surveyed elderly people stated that they were not currently undertaking PA. The analysis of the reported activities by gender showed that all people participating in organized physical activities were women (women: 8.5\%, men: 0.0\%; $\mathrm{p}=0.01$ ). As regards other activities, no statistically significant differences were found between the surveyed women and men.

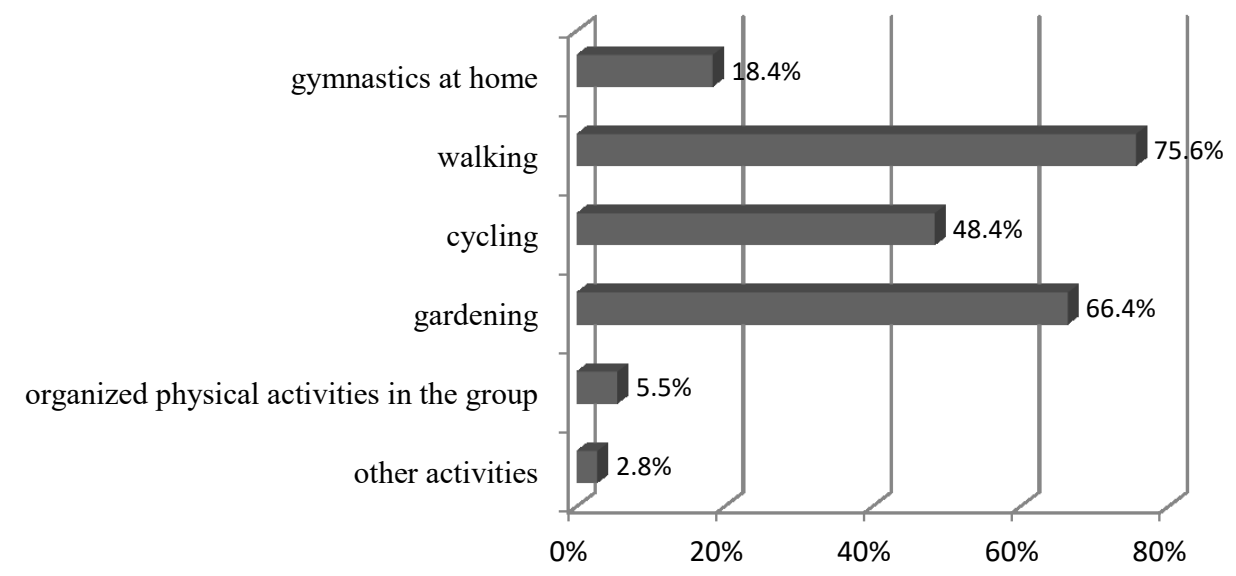

Figure 1. Different physical activities currently done by respondents

Walking (36.9\%) and cycling (35.9\%) dominated the physical activities that respondents would like to do (Figure 2), followed by gymnastics at home (29.5\%) and gardening (26.3\%). The gender analysis showed that women significantly more often reported willingness to participate in organized physical activities (women: 21.1\%, men: 8.0\%; $\mathrm{p}=0.013$ ). As regards other activities, no statistically significant differences were found between the surveyed women and men. 


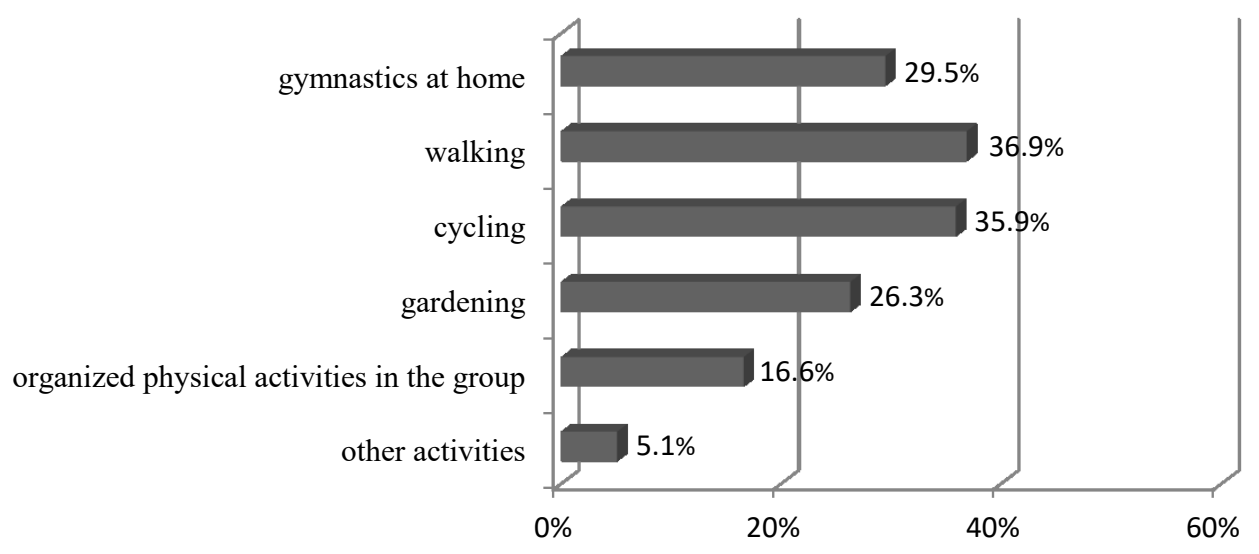

Figure 2. Different physical activities that respondents would like to do

As the limitations preventing them from undertaking PA (Figure 3), most respondents indicated disability, physical weakness, fears, and multiple morbidities (34.6\%). The inability to organize a specific PA was reported by $27.7 \%$ of respondents, while lack of self-determination overcoming reluctance and motor laziness was reported by $23.5 \%$. As many as $19.4 \%$ of respondents believed that elderly people should rest a lot and limit their physical efforts. Among the analyzed limitations, no statistically significant differences were found between the declarations of women and men.

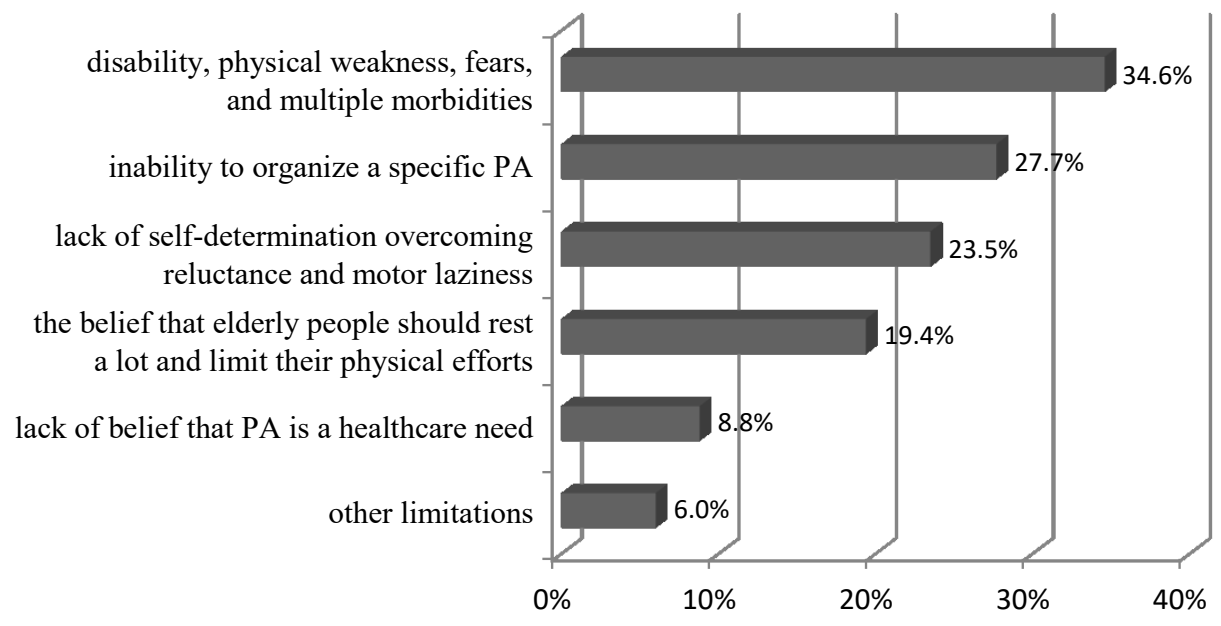

Figure 3. Limitations reported by the elderly that currently prevent them from taking up physical activity

Lack of PA or its deficiency referred to in the literature as the phenomenon of hypokinesia, contributes to many physical and mental diseases. According to the surveyed elderly, the diseases that may be caused by hypokinesia are mainly obesity, musculoskeletal diseases, and arterial hypertension. Detailed results are illustrated in Figure 4. 


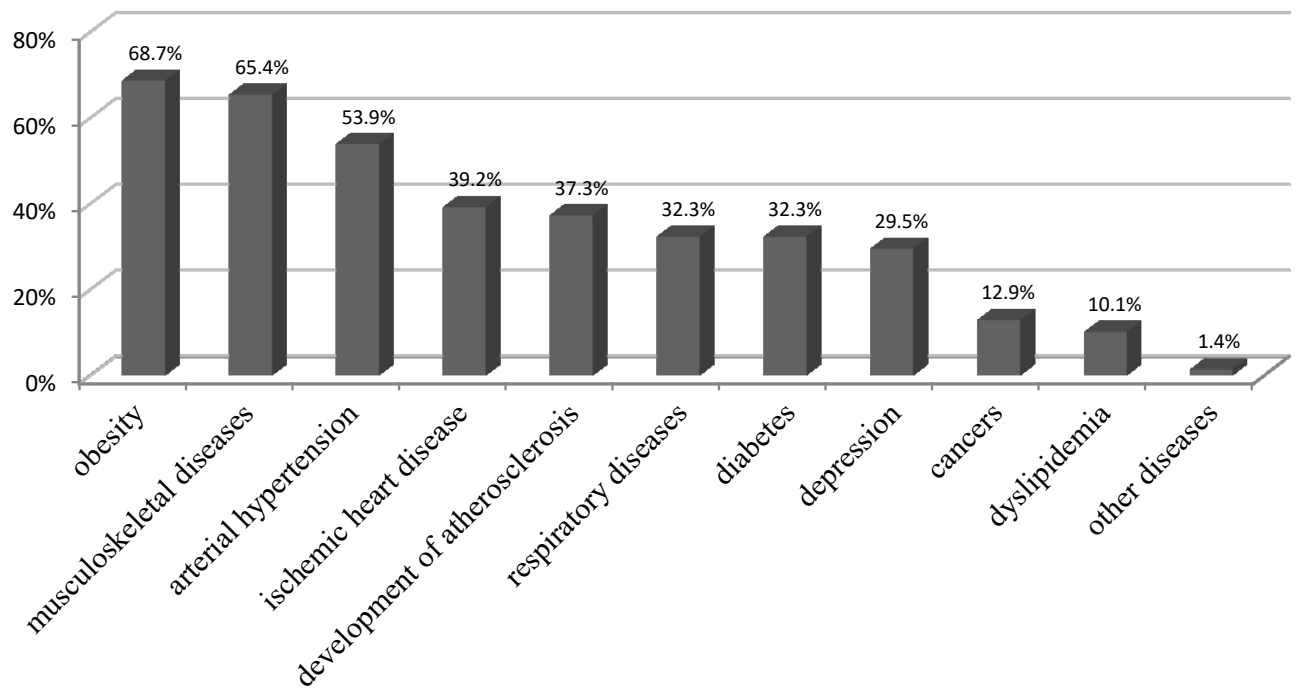

Figure 4. Diseases worsened by hypokinesia according to the respondents

\section{Discussion}

According to the results of the European Health Interview Survey, the majority of elderly people assess their health as middling, that is neither good nor bad (43\%), 29\% of respondents assessed it as bad and very bad, and only $28 \%$ of the elderly considered their health very good and good [21]. Most surveyed elderly people assessed their health as good. The CSO study demonstrated that the assessment of one's own health deteriorates with the passing years of life. Among 60-year-olds, every third person assessed their health as very good or good, and only every fifth person assessed it as bad or very bad. Among the oldest people (80 years and more), every second person reported bad or very poor health, and only every eighth person reported at least good health [22]. Elderly people able to actively participate in everyday life rated their health very high, claiming that in addition to proper diet and family support, physical exercise is a recipe for longevity [23].

The authors of this study investigated the level of PA of the elderly people earlier in life and currently. It was found that the earlier PA of the respondents had been mostly sporadic. PA had been done systematically only by every third person. PA done systematically had been related to household and backyard chores, professional work, and physical education lessons. According to Marchewka and Jungiewicz, undertaking physical effort before the age of 35 has a positive effect on motivation and willingness to engage in PA in old age, and people who are more active in their youth are more active in old age [24].

The Polish Central Statistical Office survey on the participation of Poles in PA indicated that people aged 60 or more rarely participate in sports or physical recreation - only every fourth person $(25.1 \%)$ does such activity. The declaration of regular participation was made by $10.6 \%$ of the elderly, while $14.5 \%$ of respondents reported occasional effort. Men in this age group were slightly more physically active than women. The most popular sports and recreational activity was cycling (71.5\% of exercising residents of Poland). It dominated in all age groups, also among people aged 60 and over (64.6\%). Jogging and Nordic walking were also very popular among older respondents. It was emphasized that with age, the number of people participating in these forms of recreation increases and amounts to every fourth person above 60 years of age (27\%). Subsequently, people aged 60 and over participated in general development activities, improving their physical condition (20\%) [20]. In this study, the most frequent activities were found to be walking and gardening. Cycling came third, with almost half of respondents. These are usually exercises of varying intensity, providing endurance effort. The most popular forms of PA that respondents would like to do were walking and cycling. It is worth noting that the will to do independent home gymnastics and organized physical activities in the group was reported by more respondents than by those who reported to do these physical activities. Among the surveyed elderly people, the opportunity to participate in organized group activities is significantly more popular among women.

The limitations which, in the opinion of the respondents, prevent them from undertaking PA are disability (the greatest degree), perceived physical weakness, as well as anxiety and multiple morbidities. To a lesser extent, lack of own skills needed to organize the physical effort and lack of determination overcoming reluctance to move (kinesiophobia) were indicated. It should be emphasized that as many as every fifth respondent was convinced that the elderly should rest a lot and limit their physical efforts, which reveals seniors' lack of reliable 
knowledge on this subject. The CSO study indicated age as the main obstacle (according to 36.4\%) among the limitations preventing participation in sports and physical recreation by people above 60 years of age. Health state and contraindications by the physician (32.4\%) were another barrier. In the case of $14.0 \%$ of the elderly respondents, the failure to participate in this type of activity resulted from lack of interest and willingness or from the preference for passive rest [25].

The beneficial health-promoting effect of PA on the human body results from many scientifically-proven mechanisms. The WHO Report (2002) demonstrated that hypokinesia is responsible for $15.0 \%$ of new cases of cancer, diabetes, and heart diseases. Systematic, moderate PA has a significant impact on improving general health, quality of life, and the course of many civilization diseases, for example, diabetes. PA improves glucose metabolism, contributes to the reduction of adipose tissue, lowers blood pressure, lowers the concentration of glycated hemoglobin (HbA1c), and reduces body weight and waist circumference [16]. It must be admitted that respondents' knowledge about the importance of PA in the prevention of many diseases (threats) seems superficial. The largest percentage of respondents was convinced that hypokinesia contributes to obesity, musculoskeletal diseases, and arterial hypertension.

\section{Conclusions}

The level of PA of the surveyed elderly people, limitations preventing PA, and low level of knowledge about the delayed consequences of hypokinesia suggests that health education of the elderly, in physioprophylaxis, is warranted.

\section{References:}

1. Bijnen FC, Feskens EJ, Caspersen CJ, Nagelkerke N, Mosterd WL, Kromhout D. Baseline and pevious physical activity in relation to mortality in elderly men: the Zutphen Elderly Study. Am J Epidemiol. 1999; 150(12): 1289-1296. https://doi.org/10.1093/oxfordjournals.aje.a009960

2. Friedenreich CM, Orestein MR. Physical activity and cancer prevention: etiologic evidence and biological mechanisms. J Nutr. 2002; 132(11 Suppl.): 3456S-3464S. https://doi.org/10.1093/jn/132.11.3456S

3. Drygas W, Jegier A. [Recommendations for physical activity in the prevention of cardiovascular diseases]. Czynniki Ryzyka: Pismo Polskiego Towarzystwa Badań nad Miażdżycą. 2003; 4/02-1/03(38/39): 76-84 (in Polish).

4. Drygas W, Piotrowicz R, Jegier A, Kopeć G, Podolec P. [Physical activity of healthy people]. In: Podolec P., editor. [Handbook of the Polish Prophylaxis Forum. Vol. 2]. Kraków: Medycyna Praktyczna; 2010. p. 437-442 (in Polish).

5. Zdrojewski T, Rutkowski M, Bandosz P, Gaciong Z, Solnica B, Drygas W, et al. [Control and assessment of prevalence of cardiovascular diseases risk factors in Poland - NATPOL research 1997, 2002, 2011]. In: Kopeć G, Jankowski P, Pająk A, Drygas W., editors. [Epidemiology and prevention of cardiovascular diseases. Vol. 2]. Kraków: Medycyna Praktyczna; 2015. p. 57-64 (in Polish).

6. Piepoli MF, Hoes AW, Agewall S, Albus C, Brotons C, Catapano AL, et al. 2016 European guidelines on cardiovascular disease prevention in clinical practice: The Sixth Joint Task Force of the European Society of Cardiology and Other Societies on Cardiovascular Disease Prevention in Clinical Practice (constituted by representatives of 10 societies and by invited experts). Developed with the special contribution of the European Association for Cardiovascular Prevention \&Rehabilitation (EACPR). European Heart Journal. 2016; 37(29): 2315-2381. https://doi.org/10.1093/eurheartj/ehw106

7. Soares-Miranda L, Siscovick DS, Psaty BM, Longstreth WT Jr, Mozaffarian D. Physical activity and risk of coronary heart disease and stroke in older adults: the cardiovascular health study. Circulation. 2016; 133(2): 147-155. https://doi.org/10.1161/CIRCULATIONAHA.115.018323

8. Piotrowicz R, Drygas W, Kopeć G, Podolec P. [Physical activity of people with cardiovascular diseases]. In: Podolec P., editor. [Handbook of the Polish Prophylaxis Forum. Vol. 2]. Kraków: Medycyna Praktyczna; 2010. p. 443-446 (in Polish).

9. Jegier A. [Physical activity in health promotion and prevention of chronic diseases]. In: Jegier A, Nazar K, Dziak A., editors. [Sports medicine]. Warszawa: PTMS; 2006. p. 403-456 (in Polish).

10. Kostka T. [Physical activity and ageing of an organism]. In: Jegier A, Nazar K, Dziak A., editors. [Sports medicine]. Warszawa: PTMS; 2006. p. 457-464 (in Polish).

11. Kostka T, Kostka J. [Health training of elderly people]. In: Wieczorowska-Tobis K, Kostka T, Borowicz AM., editors. [Physiotherapy in geriatrics]. Warszawa: PZWL; 2011. p. 31-44 (in Polish). 
12. Marchewka A, Dąbrowski Z, Żołądź JA., editors. [Physiology of ageing. Prophylaxis and rehabilitation]. Warszawa: Wydawnictwo Naukowe PWN; 2012 (in Polish).

13. Gębka D, Kędziora-Kornatowska K. [Benefits of health training in elderly people]. Probl Hig Epidemiol. 2012; 93(2): 256-259 (in Polish).

14. Osiński W. [Gerokinesiology. Learning and practicing physical activity in old age]. Warszawa: PZWL; 2013 (in Polish).

15. Makarczuk A, Kowalska JE. [Physical activity of the students of the Third Age University]. Exlibris Biblioteka Gerontologii Społecznej. 2016; 1(11): 147-159 (in Polish).

16. World Health Organization. The world health report 2002 - reducing risks, promoting healthy life [Internet]. Geneva: World Health Organization; 2002 [cited 2020 Sep 15]. Available from: https://www.who.int/ whr/2002/en/

17. World Health Organization. Global recommendation on physical activity for health [Internet]. Geneva: World Health Organization; 2010 [cited 2020 Sep 15]. Available from: https://www.who.int/dietphysicalactivity/ factsheet_recommendations/en/

18. EU Working Group "Sport \& Health". EU physical activity guidelines. Recommended policy actions in support of health-enhancing physical activity [Internet]. Brussels: European Commission; 2008 [cited 2020 Sep 15]. Available from: https://eacea.ec.europa.eu/sites/eacea-site/files/eu-physical-activity-guidelines-2008.pdf

19. Błędowski P, Szatur-Jaworska B, Szweda-Lewandowska Z, Kubicki P. [Report concerning the situation of the elderly in Poland]. Warszawa: Instytut Pracy i Spraw Socjalnych; 2012 (in Polish).

20. GUS. [Participation in sports and physical recreation in 2016]. Warszawa: GUS; 2017 (in Polish).

21. GUS. [Health and health behavior of inhabitants of Poland in the context of European Health Survey (EHIS) 2014 (the information note of $1^{\text {st }}$ December 2015)]. Warszawa: GUS; 2015 (in Polish).

22. GUS. [60+ population. Demographic structure and health the note prepared for the sitting of the Parliamentary Commission of Senior Policy regarding "Information from the Minister of Health on the influence of demographic changes and ageing society on the healthcare system organization and National Health Program"]. Warszawa: GUS; 2016 (in Polish).

23. Skotnicka M, Pieszko M. [Physical activity is the key to longevity]. Medycyna Ogólna i Nauki o Zdrowiu. 2014; 20(4): 379-383 (in Polish). https://doi.org/10.5604/20834543.1132040

24. Marchewka A, Jungiewicz M. [Physical activity in early years of life versus quality of life in old age]. Gerontologia Polska. 2008; 16(2): 127-130 (in Polish).

25. GUS. [The situation of older people in Poland in 2018]. Warszawa, Białystok: GUS; 2020 (in Polish). 